\title{
Ecstasy (MDMA) and its Relationship with Self- Report Depression, Anxiety and Schizotypy
}

\section{Éxtasis (MDMA) y su relación con la depresión, ansiedad y esquizotipia autoinformadas}

\author{
Lisa Wood \\ Greater Manchester West Mental Health NHS Foundation Trust
}

\author{
Emma Barkus \\ University of Wollongog
}

\begin{abstract}
Aims: The relationship between ecstasy and affective psychological symptoms are still subject to debate. We aimed to examine the relationship between Ecstasy use and self-report depression, anxiety and schizotypy. Design: Data were collected via structured remote self-report questionnaires. Participants: Participants were split into three groups: a control group with no ecstasy use, a light ecstasy user group ( $<50$ times), and a heavy ecstasy user group ( $>50$ times). Measurements: Amount and patterns of ecstasy use were recorded, the Beck Depression Inventory (BDI), and Beck Anxiety Inventory (BAI) measured depression and anxiety respectively, and schizotypal traits were measured using the schizotypal Personality Questionnaire (SPQ). Findings: It was found that ecstasy use was associated with depression, anxiety and schizotypal trait scores. There was no relationship between these measures and the level of ecstasy use. Conclusions: Ecstasy use per se was associated with self-report depression and anxiety, replicating previous literature. Furthermore, ecstasy users reported more schizotypal traits, something which had not been investigated in any previous research.

Key words: ecstasy, MDMA, 3, 4- methlenedioxymethamphatamine, depression, anxiety, schizotypy, serotonin.
\end{abstract}

Resumen. Objetivos: la relación entre el consumo de éxtasis y síntomas afectivos es aún objeto de debate. Nuestro objetivo es examinar la relación entre el consumo de éxtasis y la depresión, ansiedad y esquizotipia autoinformadas. Diseño: los datos fueron recogidos a través de medidas de autoinforme estructuradas. Participantes: los participantes se dividieron en tres grupos: grupo control que no consumía éxtasis, grupo de consumidores de éxtasis en grado bajo ( $<50$ veces), y grupo de consumidores de éxtasis grado alto ( $>50$ veces). Instrumentos: se registró la cantidad y patrón de consumo de éxtasis, y se utilizó el Inventario de Depresión de Beck (BDI) para evaluar depresión, el Inventario de Ansiedad de Beck (BAI) para evaluar ansiedad, y el Cuestionario de Personalidad Esquizotípica (SPQ) para evaluar rasgos esquizotípicos. Resultados: el consumo de éxtasis está relacionado con las puntuaciones de rasgo de depresión, ansiedad y esquizotipia. No se ha encontrado relación entre las medidas de autoinforme y el grado de consumo de éxtasis. Conclusiones: el consumo de éxtasis se relaciona con las puntuaciones en depresión y ansiedad autoinformada, replicado la evidencia ya existente en la literatura. Más aún, los consumidores de éxtasis presentaron mayores puntuaciones en rasgos esquizotípicos, algo que no se había documentado en ninguna investigación anterior.

Palabras clave: éxtasis, la MDMA, 3, 4 - methlenedioxymethamphatamine, la depresión, la ansiedad, la esquizotipia, serotonina. 


\section{Introduction}

3, 4- Methlenedioxymethamphatamine (MDMA) is commonly known as ecstasy. It is one of the most widely used illegal drugs in the UK (Steele, McCann, \& Ricaurte, 1994); and the most popular with dance enthusiasts (Winstock, Griffiths, \& Stewart, 2001). In the UK approximately half a million ecstasy tablets are consumed each weekend (Saunders, 1995).

Ecstasy depletes 5-HT and 5-Hydroxindolacetic acid concentration, reduces serotonin transportation and may cause degeneration of 5-HT axon projections and nerve terminals (Gouzoulis-Mayfrank, Dauman, \& Sass, 2002). These changes could be long lasting (Cowan, 2007). Depletion of 5-HT is found in depression, anxiety, obsessive-compulsive disorders and psychosis (Naughton, Mulrooney, \& Leonard, 2000; Reneman, et al., 2002).

A relationship between ecstasy use and depressive symptoms has been associated with ecstasy users per se and current use of the drug using the Beck Depression Inventory (Beck et al, 1961) (McCardle, et al., 2004; Medina \& Shear, 2007; Roiser \& Sahakian, 2004). In contrast, when using the Symptom Checklist (SCL - 90; Derogatis, Rickels \& Rock, 1976) and SCL- 90 Revised (SCL90 R, Derogatis. 1994) a significant difference has not been found (Daumann, et al., 2001; Derogatis, 1994; Parrott, et al., 2001; Parrott, Sisk, \& Turner, 2000). Daumann et al (2004) for example, reported that controls and ecstasy users did not differ over a period of 18 months. The only significant findings of depression when using the SCL-90-R was reported by Morgan et al (2002).

Anxiety is another experience associated with ecstasy use. A longitudinal study conducted by Thomasius et al (2006) assessed current and execstasy users, polydrug users and controls and reported ex-ecstasy users had the highest anxiety scores, followed by the current ecstasy users and then the control group. These results have been replicated by other authors using the SCL-90 (Derogatis, Rickels \& Rock, 1976) and the Beck Anxiety Inventory (BAI, Beck, et al., 1988) ( e.g. Milani et al., 2004; Beck, et al., 1988; Sumnall, Wagstaff, \& Cole, 2004).
There is evidence that psychotic symptoms may be induced by recreational drugs with a particular focus on cannabis (Degenhardt \& Hall, 2002; Hides, et al., 2008). There are also some studies which have shown ecstasy can lead to a psychotic episode (e.g. McGuire and Fahy, 1991; Vaiva et al., 2001), and, similar to cannabis, a younger first use of ecstasy is associated with an earlier first episode onset of psychosis (Barnett, et al., 2007). However, as illustrated there is minimal evidence base scrutinising the link between ecstasy use and psychotic-like symptoms.

We hypothesised that ecstasy use will be associated with self-report depression, anxiety and schizotypal traits. The non-ecstasy users will have the lowest scores on all scales, with the ecstasy users scoring highest. Light ecstasy users will have intermediary scores between the controls and heavy users.

\section{Method}

\section{Participants}

Participants were recruited on an opportunity sample basis with initial contact through email and other participants being invited using 'snowball effect'. They were primarily students from the University of Manchester. There were 139 participants: 62 females (mean age 22.48, $\pm 18-26$ ) and 72 males (mean age 22.47, $\pm 18-31$ ).

\section{Materials}

Questions about frequency and pattern of Ecstasy use and polydrug use were included in the demographics data collected. Other measures included were:

1. Beck Anxiety Inventory (BAI, Beck et al, 1988) is a twenty one item list which was used to measure anxiety. The BAI has been used Ecstasy studies (e.g. Lamers, Bechara, Rizzo, Ramaekers, 2006) and is a reliable tool to measure anxiety in nonclinical samples (Creamer, Former, \& Bell, 1994)

2. Beck Depression Inventory (BDI, Beck et al 1961) was used to assess depressive symptoms. 
Schizotypal Personality Questionnaire (SPQ, Raine, 1991) measured schizotypal traits and is based on the DSM-III_R diagnostic criteria for schizotypal personality disorder. It has three factors of Cognitive Perceptual, Interpersonal and Disorganised are measured. It measure attenuated psychotic experiences, such as 'I am sure I am being talked about behind my back' (delusion of persecution) and 'Are your thoughts sometimes so strong that you can almost hear them' (auditory hallucinations).

\section{Procedure}

Data from this study came from self-report questionnaires distributed to University of Manchester students. Participants completed the questionnaire via email in their own time and were not compensated for completing this phase but were offered the opportunity to take part in a paid component of the study. Participants gave informed consent for their data to be used by returning the questionnaires to the researcher, they were informed of this in the participant information sheet. This study received ethics approval from the University of Manchester Senate Committee.

\section{Statistical Analysis}

Data was analysed using SPSS 16.0. Sample characteristics and polydrug use were compared using t-tests or ${ }^{-} \mathrm{C}$ tests to check for demographic differences. Raw data distribution did not differ significantly from normal distribution indicated by Kolmogrow-Smirnow tests. Therefore, one-way ANOVAs with Scheffe post hoc tests were applied to investigate differences between Ecstasy usage and self-report depression, anxiety and schizotypy. Results will be reported after a Bonferroni adjustment for multiple testing according to an overall alpha level of $1 \%$.

\section{Results}

Participants were split into three groups depending on ecstasy use as outlined by previous ecstasy studies, a control group (no ecstasy use), a light ecstasy users group ( $<50$ times), and a heavy ecstasy users group ( $>50$ times). Participants were split into these groups in order to scrutinise degree of use as done in previous Ecstasy studies (e.g. Parrott et al., 2001; Parrott et all, 2002). There were 42 non ecstasy using control: 21 females and 21 males with a mean age of $22.64( \pm 18-27), 60$ light ecstasy users, 26 females and 34 males with a mean age of 22.07 $( \pm 18-31)$; and, 37 heavy ecstasy users, 15 females and 22 males with a mean age of $22.44( \pm 19-31)$. These groups did not significantly differ in age ( $\mathrm{F}(2$, $133)=0.578, \mathrm{~ns})$ or gender $\left(\chi^{2}(2)=1.173, \mathrm{~ns}\right)$.

Table 1. Percentage of Polydrug Use within Each Condition

\begin{tabular}{lccc}
\hline & $\begin{array}{c}\text { Non Ecstasy } \\
\text { Users }\end{array}$ & $\begin{array}{c}\text { Light Ecstasy } \\
\text { Users }\end{array}$ & $\begin{array}{c}\text { Heavy Ecstasy } \\
\text { Users }\end{array}$ \\
\hline Alcohol & $97.61 \%$ & $100 \%$ & $100 \%$ \\
Cannabis & $30.95 \%$ & $89.29 \%$ & $97.22 \%$ \\
Poppers & $2.38 \%$ & $0 \%$ & $2.85 \%$ \\
Amphetamines & $2.38 \%$ & $8.92 \%$ & $44.44 \%$ \\
Cocaine & $2.38 \%$ & $55.35 \%$ & $94.28 \%$ \\
Magic Mushrooms & $0 \%$ & $28.57 \%$ & $36.11 \%$ \\
Ketamine & $0 \%$ & $30.36 \%$ & $58.33 \%$ \\
LSD & $0 \%$ & $23.21 \%$ & $30.55 \%$ \\
\hline
\end{tabular}

Table 1 presents the recreational drug use of all groups. Alcohol and Popper consumption did not differ between the non-ecstasy, light ecstasy and heavy ecstasy using groups, $\chi^{2}(2)=2.207, \mathrm{p}>0.05$ and $\chi^{2}(2)=2.473, p>0.05$ respectively. However all other drugs were significantly different between the three groups; cannabis $\left(\chi^{2}(2)=41.667, \mathrm{p}<0.001\right)$, amphetamines $\left(\chi^{2}(2)=48.134, \mathrm{p}<0.001\right)$, cocaine $\left(\chi^{2}(2)=38.674, \mathrm{p}<0.0005\right)$, magic mushrooms $\left(\chi^{2}(2)=77.871, \mathrm{p}<0.001\right)$, ketamine $\chi^{2}(2)=18.064$, $\mathrm{p}<0.001)$ and $\operatorname{LSD}\left(\chi^{2}(2)=18.606, \mathrm{p}<0.001\right)$ : those who used ecstasy were more likely to use other recreational drugs.

\section{Psychological Symptoms and Ecstasy Usage}

The BDI scores were lowest in the control group (mean=4.33, $\mathrm{SD}=3.55$ ), the light users were intermediatry (mean $=6.95, \mathrm{SD}=5.56$ ) and the heavy users had the highest score (mean=8.81, $\mathrm{SD}=9.27$ ). These differences were significant $(\mathrm{F}(2,138)=$ $5.045, \mathrm{p}=0.001)$, Sheffe Post hoc analysis revealed scores significantly differed between the control group and the heavy users $(\mathrm{p}=0.009)$.

For BAI scores $(\mathrm{F}(2,138)=2.97, \mathrm{p}=0.009)$ 
Scheffe post hoc analysis revealed that the control and heavy users $(\mathrm{p}=0.044)$ differed significantly from one another. The descriptive statistics were: controls: mean $=5.48, \mathrm{SD}=5.15$; light users mean $=8.10$, $\mathrm{SD}=7.82$; heavy users: mean $=9.64, \mathrm{SD}=9.86$.

For the Cognitive Perceptual dimension of the SPQ (controls mean $=5.98, \quad \mathrm{SD}=5.62 ;$ light mean $=8.16, \mathrm{SD}=5.62$; heavy users mean $=8.97$, $\mathrm{SD}=7.98$ ) and the Interpersonal dimension of the SPQ (controls: mean $=7.17, \mathrm{SD}=5.16$; heavy users: mean $=8.43, \mathrm{SD}=6.23$; light users mean=9.15, $\mathrm{SD}=6.65)$ the control group had the lowest scores, although these differences were not significant. For the Disorganised dimension of the SPQ (control mean $=3.40, \mathrm{SD}=2.76$; heavy mean $=6.24, \mathrm{SD}=4.42$; light mean=7.10, $\mathrm{SD}=3.95)$ a one-way ANOVA (F $(2,138)=12.22, \mathrm{p}<0.00025)$ scores differed significantly between the control and the light users $(\mathrm{p}=0.000)$ and the control and the heavy users $(\mathrm{p}=0.003)$.

\section{Discussion}

The main aim of this study was to investigate the relationship between ecstasy and depression, anxiety and schizotypal traits. We hypothesised ecstasy use would be associated with a significant increase in self-report depression, anxiety and schizotypal traits: the non-ecstasy users would have the lowest scores, ecstasy users the highest and light ecstasy users would be an intermediary group.

Ecstasy use had a significant effect on the selfreport depression. On the BAI controls scored significantly lower than heavy users. On the BDI the differences were in the expected direction and reached significance with the non-ecstasy users scoring significantly lower than the heavy ecstasy users after post hoc testing. For the SPQ Disorganisation dimension the control group scored significantly lower than the light and heavy users. For the other two dimensions from the SPQ the differences were in the expected direction but these did not reach significance. These findings support previous findings that ecstasy has a relationship with depressive symptoms, (McCardle, et al., 2004; Parrott, et al., 2002; Win, et al., 2006), anxiety symptoms (Cole, Sumnall and Wagstaff, 2002) and psychotic-like symptoms (Vaiva et al, 2001).

The Diathesis-Stress (DS; Parrott, 2006) model may provide insight into these findings. In this model proneness to a psychological disorder is an interaction between an underlying biological vulnerability and psychosocial factors. Drug use could be an example of a psychosocial factor even though it exerts its effects in a biological manner. According to the DS model ecstasy use can exacerbate individual vulnerability to psychological symptoms. Individual internal and external factors can collectively cause vulnerability, which may explain why degree of use did not have a significant effect on individual scores. However, further information would be needed from participants such as life stressors, personal and family psychiatric history in order to determine individual vulnerability.

Continued use of ecstasy is thought to lower levels of 5-HT and/or desensitization of the 5-HT system (Commins et al, 1987). The role of 5-HT in depression and anxiety has been well documented (Naughton, Mulrooney, \& Leonard, 2000; Reneman, et al., 2002), and the drugs which treat this disorder also target the 5-HT system (e.g. Harvey, Rudolph,\& Preskorn, 2000). The role which 5-HT may play in the onset of psychotic symptoms is less well defined, although decreases in mood may increase the likelihood of experiencing delusions (Fowler et al, 2001). Additionally the second generation atypical antipsychotics, such as Clozapine, target the 5-HT system (Dursun et al, 2000). Collectively the effects of ecstasy on the brain are sufficiently non-specific that biological vulnerability to a psychological disorder could be expressed after taking ecstasy recreationally. Particularly if those with a predisposition to a psychological disorder are more sensitive to the possible long term alterations which ecstasy can induce.

\section{Limitations}

One main issue concerning this study and many other drug-related studies is polydrug use. Ecstasy users were more likely to have used other drugs including LSD, Cocaine, Ketamine, Cannabis and 
Magic Mushroom. Previous studies have reported that ecstasy users are more likely to use cannabis (Strote, Lee and Wechsler, 2002) and other drugs such as amphetamine, cocaine and LSD when compared to only cannabis users (Fox et al., 2001). This illustrates that Ecstasy users are more likely to be polydrug users. Disentangling the possible interactions between ecstasy effects and other recreational drugs in terms of their physiological and psychological effects is a difficult task.

Furthermore, LSD, Cocaine, Ketamine, Cannabis and Magic Mushroom are also associated with depressive, anxious and psychotic-like symptoms (e.g. Patten et al., 2002) which will confound the results of the study. It has also been has shown that polydrug use in conjunction with MDMA can cause adverse effects (e.g. Williamson, et al., 1997). For example, cocaine use may increase the neurotoxicity of MDMA (Horan, Gardner, \& Ashby, 2000) and the combined use of LSD and MDMA simultaneously is problematic due to their side effects (Schechter, 1998). However unless studies specifically recruit individuals who have used or currently use only one recreational drug they will all be subject to the confound of polydrug use. Larger studies may be able to statistically control for polydrug use however this will only go some way to removing the individuals differences in drug use and the effects of this drug use on neurobiological systems. Ecstasy users score highly on personality traits such as sensation seeking and impulsivity and these traits may be an indication of why they are more likely to experiment with recreational drugs (Hanson, Luciana, \& Sullwold, 2008).

In the current study we cannot comment on whether participants were using multiple drugs in one session. It is also difficult to quantify how much ecstasy (and other drugs) an individual ingests both in one session and lifetime use. It is dependant on the individual to remember how much they have taken which can be unreliable (e.g. Dumont \& Verkes, 2006). Moreover, the amount of MDMA in a tablet is questionable, it has been found that as low as $22 \%$ of the tablet contains MDMA (GalliotGuilley, et al., 1999). In further research, careful recording of factors such as polydrug use, life-stressors, personal and family psychiatric history will allow for them to be controlled statistically at least and closer documentation of individual variation may aid the identification of vulnerability to psychological symptoms solely caused by ecstasy use.

In conclusion, we presented data of an association between degree of ecstasy exposure and depressive, and schizotypal symptoms. The association with schizotypal symptoms has not been previously documented. The results from the current study are supported by the existing literature although further studies need to focus on why some individuals may report an increase in these symptoms co-occurring with ecstasy use.

\section{Reference:}

Barnett, J., Werners, U., Secher, S., Hill, K., Brazil, R., Masson, K., et al. (2007). Substance use in a population-based clinical sample of people with first episode psychosis. British journal of psychiatry, 190, 515-520.

Beck, A.T., Ward, C.H., Mendelson, M. y Mock J., Erbaugh, J. (J1961). "An inventory for measuring depression". Archives of General Psychiatry, 4, 561-71.

Beck, A., Epstein, N., Brown, G., \& Steer, R. (1988). An inventory for measuring clinical anxiety: Psychometric properties. Journal of Consulting and Clinical Psychology, 56, 893-897.

Cole, J.C., Sumnall, H.R., Wagstaff, G.F. (2002) Methodological problems with ecstasy and the SCL-90. Psychopharmacology, 162, 215-217.

Commins, D. L., Vosmer, G., Virus, R.M., Woolverton, W. L, Schuster, C. R., Seiden, L. S. (1987). Biochemical and Histological Evidence that Methylenedioxymethlyamphetamine (MDMA) is toxic to neurons in the rat brain. Journal of Pharmacology and Experimental Therapy, 241, 338-345.

Cowan, R. (2007) Neuroimaging research in human MDMA users: a review, Psychopharmacology, 189, 539-556.

Daumann, J., Hensen, G., Thimm, B., Rezk, M., Till, B., \& Gouzoulis-Mayfrank, E. (2004). Selfreported psychopathological symptoms in recreational ecstasy (MDMA) users are mainly associ- 
ated with regular cannabis use: further evidence from a combined cross-sectional/longitudinal investigation. Psychopharmacology, 173, 398-404. Daumann, J., Pelz, S., Becker, S., Tuchtenhagen, F., \& Gouzoulis-Mayfrank, E. (2001). Psychological profile of abstinent recreational Ecstasy (MDMA) users and significance of concomitant cannabis use. Human Psychopharmacology: Clinical and Experimental, 16, 627-633.

Degenhardt, L., \& Hall, W. (2002). Cannabis and psychosis. Current Psychiatry Reports, 4, 191-196.

Derogatis, L., Rickels, K. and Rock, A. (1976) The SCL-90 and the MMPI: A step in the validation of a new self-report scale. British Journal Psychiatry, 128, 280-289.

Derogatis, L. R. (1994). Symptom Checklist - 90 - R: Administration, Scoring, and Procedures $\mathrm{Ma}$ nual. Minneapolis: National Computer Systems.

Dumont, G., \& Verkes, R. (2006). A review of acute effects of 3,4-methylenedioxymethamphetamine in healthy volunteers. Journal of Psychopharmacology, 20, 176-187.

Durnsun, S.M., Szemis, A., Andrews, H., Whitaker, p. And Reveley, M.A. (2000) Effects of Clozapine and typical antipsychotic drugs on plasma 5-HT turnover and impulsivity in patients with schizophrenia:a cross-sectional study. Journal of Psychiatry and Neuroscience, 25, 347-352.

Fowler, D.G., Freeman, D., Smith, B., Garety, P.A., Kuipers, E.K., Bebbington, P.E. \& Dunn, G. (2006) The brief core schema scales: psychometric properties and associations with paranoia, depression, and anxiety in normal and psychosis samples. Psychological Medicine.

Fox, A.C., Parrott, A.C. \& Turner, J.J.D. (2001) Ecstasy use: cognitive deficits related to dosage rather than self-reported problematic use of the drug, Journal of Psychopharmacology, 15, 273281.

Galliot-Guilley, M., Sueur, C., Lebeau, B., Fompeydie, D., Benezech, A., \& Bazard, J. P. (1999). Ecstasy and it's 'counterparts'. Presse Med, 28, 358-362.

Gouzoulis-Mayfrank, E., Dauman, J., \& Sass, H. (2002). Long-term neurotoxic brain damage in ecstasy (MDMA) users. A review of the literature. Nervenarzt, 73, 405-421.
Hanson, K., Luciana, M., \& Sullwold, K. (2008). Rewaed-related decision making deficits and elevated impulsivity among MDMA and other drug users. Drug and Alcohol Dependance, 96, 99-110.

Harvey, A.T., Rudolph, R.L. \& Preskorn, S.H. (2000) Evidence of the dual mechanisms of action of venlafaxine. Archives of General Psychiatry, 57, 503-509.

Hides, L., Kavanagh, D. J., Dawe, S., \& Young, R. M. (2008). The influence of cannabis use expectancies on cannabis use and psychotic symptoms in psychosis. Drug and Alcohol Review, 1-7.

Horan, B., Gardner, E. L., \& Ashby, C. R. (2000). Enhancement of conditioned place preference response to cocaine in rats following sub-chronic administration of 3, 4-methylenedioxymethamphetamine (MDMA). Synapse, 35, 160-162.

Kelly, P. (2000) Does recreational ecstasy use cause long-term cognitive problems? Western Journal of Medicine, 173, 129-130.

McCardle, K., Luebbers, S., Carter, J., Croft, R., \& Stough, C. (2004). Chronic MDMA (ecstasy) use, cognition and mood. Psychopharmacology, 173, 434-439.

McGuire, P. \& Fahy, T. (1991) Chronic paranoid pasychosis after misuse of MDMA ("ecstasy"), British Medical Journal, 23, 302, 1150-1151.

Medina, K. L., \& Shear, P. K. (2007). Anxiety, depression, and behavioral symptoms of executive dysfunction in ecstasy users: Contributions of polydrug use. Drug and Alcohol Dependence, 87, 303-311.

Milani R.M., Parrott A.C., Turner J.J.D., Fox H.C. (2004) Gender differences in self-reported anxiety, depression and somatization among ecstasy/MDMA users, poly-drug users, alcohol/tobacco users and non-drug users. Addictive Behaviors, 29, 965-971.

Morgan, M., McFie, L., Fleetwood, L., \& Robinson, J. (2002). Ecstasy (MDMA): Are the psychological problems associated with its use reversed by prolonged abstinence? Psychopharmacology, 159, 294-303.

Naughton, M., Mulrooney, J. B., \& Leonard, B. E. (2000). A review of the role of serotonin receptors in psychiatric disorders. Human Psychopharmacology, 15, 397-416. 
Parrott, A.C. (2006) MDMA in humans: factors which affect the neuropsychobiological profiles of recreational ecstasy users, the integrative role of bioenergetic stress. Journal of Psychopharmacology, 20, 147-163.

Parrott, A., Buchanan, T., Scholey, A., Heffernan, T., Ling, J., \& Rodgers, J. (2002). Ecstasy/MDMA attributed problems reported by novice, moderate and heavy recreational users. Human Psychopharmacology: Clinical and Experimental, 17, 309-312.

Parrott, A., Milani, R. M., Parmar, R., \& Turner, J. J. (2001). Recreational ecstasy/MDMA and other drug users from the UK and Italy: psychiatric symptoms and psychobiological problems. Psychopharmacology, 159, 77-82.

Parrott, A., Sisk, E., \& Turner, J. (2000). Psychobiological problems in heavy “ecstasy' (MDMA) polydrug users. Drug and Alcohol Dependence, 60, 105-110.

Patton GC, Coffey C, Carlin JB, Degenhardt L, Lynskey M, HallW. (2002). Cannabis use and mental health in young people: cohort study. British Medical Journal, 325, 1195-1198.

Raine, A. (1991). The SPQ: A scale for the assessment of schizotypal personality based on DSMIII-R criteria. Schizophrenia Bulletin, 17, 556564.

Reneman, L., Endert, E., Bruin, K., Lavalaye, J., Feenstra, M., Wolff, F., et al. (2002). The Acute and Chronic Effects of MDMA ("Ecstasy") on Cortical 5-HT2A Receptors in Rat and Human Brain Neuropsychopharmacology, 26, 387-396.

Roiser, J. P., \& Sahakian, B. J. (2004). Relationship between ecstasy use and depression: a study controlling for poly-drug use. Psychopharmacology, 173, 411-417.

Saunders, N. (1995). Ecstasy and the dance culture. London: Neal's Yard Publishing.
Schechter, M. D. (1998). 'Candyflipping': synergistic discriminative effect of LSD and MDMA European Journal of Psychopharmacology, 341, 131-134.

Strote, J., Lee, J.E. \& Wechsler, H. (2002). Increasing MDMA use among college students: result of a national suervey. Journal of Adolescent Health, 30, 64-73.

Steele, T. D., McCann, U. D., \& Ricaurte, G. A. (1994). 3, 4-methylenedioxymethamphetamine (MDMA, 'Ecstasy'): Pharmacology and Toxicology in Animals and Humans. Addiction, 89, 539-551.

Sumnall, H., Wagstaff, G., \& Cole, C. (2004). Selfreported psychopathology in polydrug users. Journal of Psychopharmacology, 18, 75-82.

Thomasius, R., Zapletalova, P., Petersen, K., Buchert, R., Andresen, B., Wartberg, L., et al. (2006). Mood, cognition and serotonin transporter availability in current and former ecstasy (MDMA) users: The longitudinal perspective. Journal of Psychopharmacology, 20, 211-225.

Vaiva, G., Boss, V. Bailly, D. Thomas, P., Lestavel, P. \& Coudemand, M. (2001) An 'accidental' acute psychosis with ecstasy use. Journal of psychoactive drugs, 33, 95-98.

Williamson, S., Gossop, M., Powis, B., Griffiths, P., Fountain, J., \& Strang, J. (1997). Adverse effects of stimulant drugs in a community sample of drug users. Drug and Alcohol Dependence, 44, 87-94.

Win, M., Schilt, T., Reneman, L., Vervaeke, H., Jager, G., \& Dijkink, S. (2006). Ecstasy Use and Self-Reported Depression, Impulsivity and Sensation Seeking: A prospective Cohort Study. Journal of Psychopharmocology, 20, 226-235.

Winstock, A. R., Griffiths, P., \& Stewart, D. (2001). Drugs and th dance music scene: a survey of current drug use patterns among a sample of dance enthusiasts in the UK. Drug and Alcohol Dependance, 64, 9-17.

Manuscrito recibido: 07/04/2010

Revisión recibida: $15 / 04 / 2010$

Manuscrito aceptado: 28/04/2010 